\title{
Policy Analysis on Bio and Wood Energy Development in East Kalimantan
}

\author{
Tien Wahyuni ${ }^{1, *}$ \\ ${ }^{1}$ Research and Development Centre for Dipterocarps Forest Ecosystems. Jl A.W. Syahrani, Samarinda 75124, East \\ Kalimantan, Indonesia \\ *Corresponding author. Email: yunitien@hotmail.com
}

\begin{abstract}
East Kalimantan relies heavily on fossil fuels, including diesel and coal, for on-grid power and diesel generator sets for off-grid power. The development of wood energy is one way to utilize forest products that are currently underway. Various efforts and research projects have been conducted, but there are still barriers to implementation and practice in the field. This study aims to identify potential barriers and policies proposed in the framework for the successful development of bio and wood energy in East Kalimantan. Data collected through documents study, interviews, and observation, using content analysis. The result showed that the existing local policies and regulations had supported efforts to accelerate bio and wood energy development. The necessary number of policy interventions were identified to support bio and wood energy investment by improving financial performance, technical and human capacity, and integrated planning dan reducing business and regulatory risks. While the proposed policies to address the barriers that will support the successful development of bio and wood energy are macroeconomic and market policies, financial investment policies, operational and enabling policies and legal-regulatory policies.
\end{abstract}

Keywords: Fossil Fuel, Wood Energy, Content Analysis, Policy Intervention

\section{INTRODUCTION}

A relatively high economic growth in East Kalimantan (approximately 10\% per year) fueled the growth of electricity demand is also high (about $8.7 \%$ per year) with the largest share of users in the household sector (about 60\%). As a result, the electrical system's condition is difficult to keep pace with the high electrical load. East Kalimantan province still has a power deficit of approximately 130 megawatts (MW) (Power Supply Business Plan by State Electricity Company 2015-2024 (Rencana Usaha Penyediaan Tenaga Listrik - RUPTL PLN 2015-2024). Thus, the Provincial Government of East Kalimantan plans to develop several additional generators using fuel widely available in the province, namely coal, oil, natural gas, new and renewable energy (hydropower, solar power and bioenergy).

East Kalimantan has great potential for the development of bio and wood energy. Based on data from the Ministry of Environment and Forests in 2014, East Kalimantan's production forest area is 9.34 million ha. From the area, 83 companies awarded License of Utilization Timber Forest Products in Natural Forest
(IUPHHK-HA) with a working area of approximately 5.29 million ha and License of Utilization Timber Forest Products in Forest Plantation (IUPHHK-HT) with a working area of about 1.8 million ha. East Kalimantan launched to produce woody biomass for energy by managing forest plants of energy, including utilizing degraded lands by revegetation planting and reclaiming land mines, rehabilitate watershed (Daerah Aliran Sungai $=$ DAS). All activities are performed by the mining company, which holds Borrow and Use of Forest Area Permit (IPPKH) and building energy plantation on degraded land belongs to the village and the community.

In terms of the technological development of bio and wood energy in East Kalimantan, some areas have also applied. The power plant with bioenergy fuels has been built, namely (1) Biogas Power Generation (Pembangkit Listrik Tenaga Biogas = PLTBg) $($ Cakra and Perdana Biogas Power Plant by PT. REA Kaltim) in Kembang Janggut District, Kutai Kartanegara regency by using palm oil mill effluent (POME). This power plant is the largest in Indonesia. Meanwhile, power plants with biomass fuels of wood-based forestry have been in operation, namely (2) Biomass Power Plant 
(Pembangkit Listrik Tenaga Biomass $=$ PLTBm) owned by PT Mangkujenang Harmonis Sinergy with a capacity of $5 \mathrm{MW}$ which will be increased to $10 \mathrm{MW}$ and its electricity supply to the Mahakam system with excess power scheme; (3) PT Kyong Dong Minerals also produces plant fuel in the form of wood pellets from fine wood chips, a waste wood industry of PT SBSA (PT. Sarana Bina Alam Semesta) of the Sinar Mas Group in Muara Kaman with a production capacity of 67,000 tons per year.

The development of bio and wood energy as a renewable energy resource needs three major parts. Those are energy plantation forest as "mine of energy", conversion facility of bio and wood energy and infrastructure at the end-user level. In the development of biomass energy, particularly electricity generation, the security of supply and price of biomass in the long term is essential. In addition, to generate optimum energy output, the correspondence between types of biomass utilized with the technology is also an aspect that should receive great attention. Advantages of biomass energy are allowed to be developed in remote areas or islands to be the growth of energy crops.

The drive for innovation and the role of policies and regulations that support the assurance of raw materials of bio and wood energy are very important and necessary. In the long run, demand will motivate stakeholders to conserve and improve forest management and develop critical lands into energy plantation forests. East Kalimantan's local government expects private investment and multi-stakeholder support to develop bio and wood energy infrastructure at various scales to encourage developments. However, some potential problems and barriers are still an obstacle in extensively implementing and practicing in the field. It is necessary to identify potential barriers and proposed policies in order to encourage the successful development of bio and wood energy in East Kalimantan.

\section{METHODS}

\subsection{Study Area}

This research was conducted in the province of East Kalimantan (Figure 1). This province was selected purposively based that the policies are more conical at the provincial level, taking into account the biophysical conditions and expected final energy to contribute to regional development. The research was conducted during 2015 and 2016.

\subsection{Data Collection Method}

\subsubsection{Primary Data}

Primary data were collected from focus group discussion (FGD), seminars and other meetings with stakeholders at the local level, as well as from interviews with the person who is considered an expert and in-depth understanding of bio and wood-based energy forest resources, such as the relevant officials, academics and researchers, businesses or other parties.

\subsubsection{Secondary Data}

Secondary data in this study was largely up-to-date data, namely in 10 years. Sources of secondary data were obtained from several media that can be accounted for truth and accuracy. These media are scientific journals and articles, papers, statistics, reports, law, legislation, regulations and other policies.

\subsection{Data Analysis}

\subsubsection{Analysis of Legislation Method (ALM)}

Analysis of legislation (ALM) is a tool to help mapping, assessment and referrals to new regulations or laws applicable (existing) indicating problematic or potentially problematic. The main reason for selecting this method is simple (easy to understand), easy to use (user friendly), and can be accounted for. Analysis of regulation with (ALM) method to be used only from legality, necessity (needs), and friendly.

\subsubsection{Content Analysis and Qualitative Descriptive Method}

Data collected were analyzed by using content analysis and qualitative descriptive analysis. Content analysis is used to examine the papers of regulations and policies related to bio and wood energy development efforts underway in East Kalimantan. Qualitative descriptive analysis is used to describe the quality of data in a regular sentence, sequential, logical, not overlapping and effective according to research topics to facilitate the understanding and interpretation of the data. The above analysis is to evaluate policies and wood bioenergy development in East Kalimantan. 


\section{RESULTS AND DISCUSSION}

\subsection{Results}

\subsubsection{General Overview of the Potential Development of Bio and Wood Energy in East Kalimantan}

East Kalimantan Province is committed to realizing the sustainable green development that has been implemented since 2010 in the Kaltim Green Movement. To reinforce this commitment, East Kalimantan redeclares a big movement entitled Green Growth Compact (GGC). GGC aims to accelerate and expand environmentally friendly development in East Kalimantan's entire region following policies, regulations, programs, targets, and time frame outlined at the provincial level. East Kalimantan is a province of the three provinces of Indonesia with the highest emission of Green House Gases (GHG) since a land with forest cover potentially implements green economic growth and potential and the granary of biomass energy. Utilization of biomass as a source of electrical energy profitable if assessed from the environment's protection because it does not contribute to the increase in the greenhouse gas effect.

East Kalimantan is still regarded as one of the national energy granaries, considering the number of energy sources in the province's territory in petroleum, natural gas, and coal. But on the other side of some areas in East Kalimantan had an energy deficit. Most of the energy resources in Kalimantan exported out of the region, both for the fulfillment of export to overseas and domestic use. The exploitation of coal is massively leaving critical lands that can not be used productively. According to data from the Ministry of Forestry, the total area of critical land in the province of East Kalimantan until 2013 has reached 7.800.400 million ha of degraded land. Details, land category rather critical $6,888,254$ ha, critical 848.887 ha and very critical 63.259 ha.

Based on BPDAS Mahakam Berau (Watershed Management Agency) statistical data in 2010, which has a working area covers thirty-one watersheds in East Kalimantan. The working area consists of various levels of criticality land. The total area of land included in the critical land area in the province of East Kalimantan area 3.648.79,44 ha. The critical land area in East Kalimantan is about $976,97.78$ ha. In comparison, the category of a rather critical land area of $8,247,907.07$ ha, the total area of the potential critical land area of $7,440,426.49$ ha, while the category is not a critical land area is 2.585.840,76 ha. Availability of critical land in East Kalimantan makes no land competition for other uses. The development of bio and wood energy deservedly takes advantage of critical lands.
A total of 34 (thirty-four) Production Forest Management Unit (KPHP) in East Kalimantan Province has set its working area by Ministerial Decree No. SK. 674/Menhut-II /2011, with an area of 12,567,139 hectares. At the site level, KPHP can be a very large role as a provider and manager of energy, and KPHP can determine its role under the potential and condition of forests in the region.

\subsubsection{Policy of Bio and Wood Energy Development in East Kalimantan}

Some local regulations related to the development of bio and wood energy in particular and supporting renewable energy (EBT) issued by the Government of East Kalimantan can be seen in Table 1.

\subsection{Discussion}

Bio and wood energy utilization are still very low considering many obstacles, such as the cost of investment and the selling price of electricity is relatively higher than fossil energy. Potential resources are generally small and scattered, poor infrastructure, and lack of success story. For that, we require policy interventions are integrated vertically and horizontally. It depends on the active participation of government, especially in terms of policymaking, starting from the upstream side (Ministry of Environment and Forests) to the downstream side (the Ministry of Finance, Ministry of Agriculture, Ministry of Industry, the Ministry of State Enterprises and the Ministry of Commerce).

Some policy interventions were identified to support investment in bio and wood energy projects in East Kalimantan, such as:

(1) Improving financial performance: revenue incentives, such as feed-in tariff, carbon incentives and subsidies, easier access to domestic and foreign capital These policy interventions were carried out because the government's incentives could not attract investors to invest in the field of bio and wood energy. The utilization of bio and wood energy for electricity also faces constraints due to the feed-in-tariffs selling price (FIT), which is still deemed not to attract investors. In addition, the sale of electricity mechanism to State Electricity Company (PLN) requires the involvement of many stakeholders. Besides, the resulting fuel subsidies for biofuels can not compete.

(2) Addressing technical and human capacity: training local technicians, certification of external parties, and national guideline on a feasibility study. This is necessary because bioenergy as biofuel (BBN) experienced problems due to the absence of clear regulations on the mechanisms of production and 
Table 1. Regulations and Regional Policy Related Renewable Energy

\begin{tabular}{|c|c|c|}
\hline No. & Regulation & Target \\
\hline 1. & $\begin{array}{l}\text { Regional regulation No. } 15 \text { / } 2008 \text { on Regional Long } \\
\text { Term Development Plan of East Kalimantan Province } \\
2005 \text { - } 2025\end{array}$ & $\begin{array}{l}\text { The fulfillment of electricity supply reliable and } \\
\text { efficient }\end{array}$ \\
\hline 2. & $\begin{array}{l}\text { Regional regulation No. } 4 \text { - } 2009 \text { on the Medium } \\
\text { Term Development Plan } 2009-2013 \text { of East } \\
\text { Kalimantan Province }\end{array}$ & $\begin{array}{l}\text { Making East Kalimantan for leading energy center in } \\
\text { Indonesia }\end{array}$ \\
\hline 3. & $\begin{array}{l}\text { Governor Regulation of East Kalimantan No. } 54 \text { - } 2012 \\
\text { on Regional Action Plan for Greenhouse Gas Emission } \\
\text { Reduction on Energy, Industry and Transport in 2010- } \\
2020\end{array}$ & $\begin{array}{l}\text { Conversion of fuel / fossil energy to renewable energy } \\
\text { and energy conversion }\end{array}$ \\
\hline 4. & $\begin{array}{l}\text { East Kalimantan Governor Decree No. } 670.12 \text { / K.447 / } \\
2013 \text { on the Establishment of the Coordination Team } \\
\text { and the Technical Committee of Action and } \\
\text { Alternative Energy Utilization }\end{array}$ & $\begin{array}{l}\text { The establishment of the Coordination Team, The } \\
\text { Technical Committee of Action and Alternative Energy } \\
\text { Utilization }\end{array}$ \\
\hline 5. & $\begin{array}{l}\text { Regional regulation No. } 7 \text { - } 2014 \text { on the Regional } \\
\text { Medium Term Development Plan (RPJMD) t Provinsi } \\
\text { East Kalimantan Province } 2013 \text { - } 2018\end{array}$ & $\begin{array}{l}\text { Economic dependence on renewable and renewable } \\
\text { natural resources and improved economic structure }\end{array}$ \\
\hline 6. & $\begin{array}{l}\text { Governor Regulation No. 17/ } 2015 \text { concerning } \\
\text { Governance and licensing and Non Licensing and } \\
\text { Licensing Improving Governance in the sector of } \\
\text { Mining, Forestry and Palm Oil Plantation }\end{array}$ & $\begin{array}{l}\text { Encouraging the development of renewable energy } \\
\text { Ministry of Energy and Mineral Resources Regulates a } \\
\text { moratorium on licensing of mining, plantation and } \\
\text { forestry }\end{array}$ \\
\hline 7. & $\begin{array}{l}\text { East Kalimantan Governor Decree No. } 522 \text { / K.227 / } \\
2015 \text { on the Establishment of Biomass-Based } \\
\text { Bioenergy Development Team in the Forestry Sector }\end{array}$ & $\begin{array}{l}\text { (1) Composed master plan for development of } \\
\text { biomass-based energy, (2) Dissemination of biomass- } \\
\text { based energy development, (3) Mentoring process } \\
\text { implementation biomass-based bioenergy } \\
\text { development, (4) Providing advice and policy } \\
\text { direction in order to smooth the implementation of } \\
\text { biomass-based bio-energy development in East } \\
\text { Kalimantan forestry sector, (5) Coordination and } \\
\text { consultation to organizations/ institutions relevant }\end{array}$ \\
\hline
\end{tabular}

distribution. Amenities mixing (blending) is not yet complete in all General Fuel Filling Stations pumps. The lack of human resources in quality and quantity.

(3) Integrated planning: East Kalimantan-wide resource assessment and energy planning. The local government is still experiencing difficulties adapting the center's policies, giving the impression that regional policymaking walks alone or integrated with the central policy. The problems of the institutional side of energy generally are still complicated structures and only a formality and lack of coordination between central and local.
(4) Reducing business and regulatory risks: clearer identification of area to be electricity by PLN, faster-permitting procedures. There is no regulation or a guarantee from the government to purchase raw material supply, so that investors are reluctant to invest in the supply of raw materials. This is due to lack of socialization, a long bureaucratic procedure and convoluted or difficult, and the company's requirements to obtain the investor is not following the renewable energy company. The most important barriers to renewable energy projects' success and the proposed policies to address them are listed in the matrix (Table 2). 
Table 2. The most important barriers to the success of renewable energy projects and the proposed policies

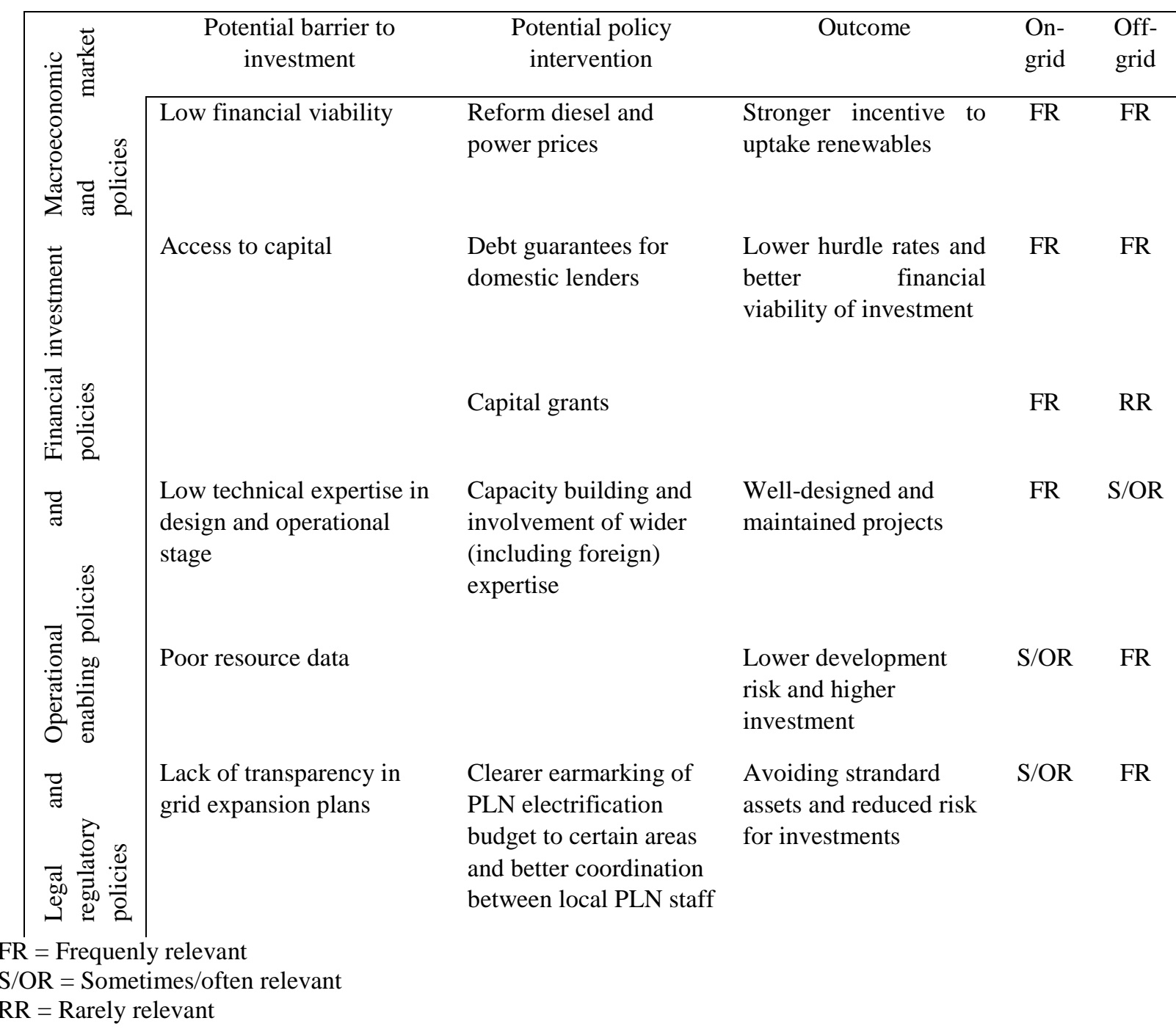

The existing local policies and regulations have been supporting efforts to accelerate bio and wood energy development. However, the necessary number of policy interventions were identified to support investment in developing bio and wood energy by improving financial performance, technical and human capacity, integrated planning dan reducing business and regulatory risks. While the proposed policies to address the barriers that will support the successful development of bio and wood energy are macroeconomic and market policies, financial investment policies, operational and enabling policies and legal-regulatory policies.

So far, the existing policy has not optimally supported the development of bioenergy in Indonesia at the national level. The central government and local governments are expected to improve and change existing policies or issue new policies to have more tangible and measurable impacts. Policies made by the government in the bioenergy sector sometimes harming or sacrificing other sectors. Therefore it should have strived that bioenergy development policy should not clash with other interests, such as the provision of food and medicines. A minimum level of government regulation policy is required: (1) Forest area management procedures for energy forests, (2) Priority of bioenergy raw materials that need to be developed, (3) Financially and economically, (4) Procedures for licensing and determination of Energy Forest Developing Enterprise, (5) Integrated bioenergy development arrangements from upstream to downstream, including the construction of supporting infrastructure, (6) Decentralized development of bioenergy facilities (for outer islands and remote areas), (7) Diversification of forest resources, production processes, product types and bioenergy markets, (7) Mandatory policy of utilization of raw materials and domestic market obligation (DMO).

A regulatory requirement for a government regulation governing: (1) Plant cultivation system related to the development of bioenergy crops, (2) 
Utilization of forests to develop bioenergy crops. For the development of energy forests, it is necessary to make a regulation on the implementation of the regulates: (1) The types of plants developed in the area of energy forests, (2) Policies that require planting of forest crops for bioenergy feedstocks, (3) Complete guidance on what types of crops can be developed in the area of energy forests, (4) Determination of areas of energy forest area development in each province. To attract investor's interest in investing in bioenergy, it is necessary to make/revise the Ministerial Regulation concerning (1) Pricing/tariff of raw materials and bioenergy products, (2) Revised ministerial regulation of ESDM on feed-in-tariff, (3) Revised regulation of finance minister expanding coverage of incentives such as exemption of import duty, tax breaks and others, (4) Establish integrated one-door services to gain incentives.

\section{CONCLUSION}

Local or provincial governments are expected to implement national bioenergy policies to integrate land availability with climatic and geographic conditions, the suitability of biomass species, local community and industry conditions, availability of supporting infrastructure, investment economics, and the project itself energy needs in each region, respectively. Cooperation between ministries or between central and local governments as well as between governments and the private sector, such as the MOUs between the Ministry of Environment and Forestry (KLHK) with the Ministry of Energy and Mineral Resources for the development of energy forests, needs to be improved, expanded and followed up in earnest and can be implemented in the field. For bioenergy development to work appropriately, planning should be made from central, provincial to site level. The site-level implementation also requires coordination with local KPHP. At the site level, identification of existing plants and plants that can be developed in the area. Once identified it could be applied appropriate processing technology and production technology.

\section{ACKNOWLEDGMENTS}

We are grateful to Wahyudi Manaff, Tunggul Butarbutar, Alfan Subekti and for their contributions and information. We are also thankful to participants of the National Seminar on September 28, 2016, with theme 'East Kalimantan as Biomass Energy: Sustainable Green Energy Development To Support the Green Growth Compact (GGC) Movement in East Kalimantan', initiated by the Fahutan Alumni Association of Mulawarman University, Forestry Service East Kalimantan Province and East Kalimantan Provincial Government.

\section{REFERENCES}

[1] D. Aryani, Skenario Kebijakan Energi Hingga Tahun 2035, Disertasi Sekolah Pasca Sarjana Universitas Indonesia, Depok, 2012.

[2] E. Heyko, Z. Hasid, Priyagus, Strategi Pemanfaatan Energi Terbarukan Dalam Rangka Kemandirian Energi Daerah Kalimantan Timur, INOVASI: Jurnal Ekonomi Keuangan dan Manajemen, 12(1), 2016, ISSN print: 0216-7786, ISSN $\quad$ online: 2528-1097. http://journal.feb.unmul.ac.id

[3] A.P. Tampubolon, Kajian Kebijakan Energi Biomassa Kayu Bakar, Bogor, 2008.

[4] T.H. Soerawidjaja, Peran Bioenergi dan Arah-Arah Utama LitBangRap-nya di Indonesia, Institut Teknologi Bandung (ITB), 2010.

[5] T.H. Soerawidjaja, Challenges of Biofuel Development in Indonesia, Institut Teknologi Bandung (ITB), 2011.

[6] T.H. Soerawidjaja, Teknologi Pemanfaatan Biomassa Berbasis Sumber Daya Hutan Sebagai Pembangkit Energi: Potensi, Tantangan dan Rekomendasi Kebijakan, Institut Teknologi Bandung, 2015.

[7] Kementerian Kehutanan, Pembangunan Kesatuan Pengelolaan Hutan (KPH), Direktorat Jenderal Planologi Kehutanan, Direktorat Wilayah Pengelolaan dan Penyiapan Areal Pemanfaatan Kawasan Hutan, Jakarta, 2011.

[8] Pemerintah Provinsi Kalimantan Timur, Strategi dan Rencana Aksi Provinsi (SRAP) Implementasi REDD+, Satgas REDD+, Samarinda, 2012.

[9] Kementerian Kehutanan, Statistik Kementerian Kehutanan Tahun 2013: Statistik Kawasan Hutan 2013, Direktorat Perencanaan Kawasan Hutan, Direktorat Jenderal Planologi Kehutanan, Kementerian Kehutanan, 2014.

[10] Direktorat Kehutanan dan Konservasi Sumber Daya Air Kementerian Perencanaan Pembangunan Nasional/Bappenas, Strategi Pengembangan Energi Berbasis Sumber Daya Hutan (Forest Based Energy), Meningkatkan Peranan KPHP Sebagai Lumbung Energi, 2015.

[11] Global Green Growth Institute, Renewable Energy. A green Growth Assessment in Kalimantan, 2015.

[12] Regional Regulation, Regional regulation No. 15/2008 on Regional Long Term Development Plan of East Kalimantan Province 2005-2025, 2008. 
[13] Local regulation No. 4 - 2009 on the Medium Term Development Plan 2009 - 2013 of East Kalimantan Province

[14] Governor Regulation of East Kalimantan No. 54 2012 on Regional Action Plan for Greenhouse Gas Emission Reduction on Energy, Industry and Transport in 2010-2020

[15] Governor Regulation, East Kalimantan Governor Decree No. 670.12/K.447/2013 on the Coordination Team and the Technical Committee of Action and Alternative Energy Utilization, 2013.

[16] Governor Regulation, Governor Regulation No. 17/2015 concerning Governance and licensing and Non-Licensing and Licensing Improving Governance in Mining, Forestry and Palm Oil Plantation, 2015.

[17] Governor Regulation, East Kalimantan Governor Decree No. 522/K.227/2015 on the Establishment of Biomass-Based Bioenergy Development Team in the Forestry Sector, 2015. 